\title{
Spontaneous closure of the hymen during term pregnancy
}

\author{
Gomathy E. ${ }^{1}$, Poonguzhali Liston ${ }^{1 *}$, Shilpa G. ${ }^{2}$ \\ ${ }^{1}$ Department of Obstetrics and Gynecology, Sri Devraj Urs Medical college, Kolar, Karnataka, India \\ ${ }^{2}$ Department of Pathology, MVJ Medical College, Hoskote, Karnataka, India
}

Received: 30 March 2017

Accepted: 17 June 2017

\section{*Correspondence:}

Dr. Poonguzhali Liston,

E-mail: sw_81989@hotmail.com

Copyright: () the author(s), publisher and licensee Medip Academy. This is an open-access article distributed under the terms of the Creative Commons Attribution Non-Commercial License, which permits unrestricted non-commercial use, distribution, and reproduction in any medium, provided the original work is properly cited.

\begin{abstract}
The hymen is a thin fold of mucous membrane; partially closing the external vaginal opening. 1It is composed mainly of elastic, collagenous connective tissue and covered on its both surfaces by stratified squamous epithelium. At pregnancy, the epithelium of hymen becomes very thick and rich in glycogen, which may lead to spontaneous closure. We aim to report a rare case of spontaneous closure of hymen in a 23-year old primigravida in labour with no prior history of menstrual problems or problems during intercourse. Two conditions can cause the secondary closure of the hymen: following previous scarring and in pregnancy. In pregnancy, it could be spontaneous closure due to increase glycogen content of the hymen or due to extensive scarring as seen in previous hymenal surgeries. Spontaneous closure of hymen during pregnancy though very rare can occur. Along with extensive scarring, prolonged abstinence and oestrogenic effect on hymen, gonococcal infection can also cause sponatenous closure of hymen during pregnancy.
\end{abstract}

Keywords: Hymen, Pregnancy

\section{INTRODUCTION}

The hymen is a thin fold of mucous membrane; partially closing the external vaginal opening. ${ }^{1}$ It is composed mainly of elastic, collagenous connective tissue and covered on its both surfaces by stratified squamous epithelium without any evidence of cornification. The human female is the only primate to possess a hymen. At pregnancy, the epithelium of hymen becomes very thick and rich in glycogen, which may lead to spontaneous closure. The case presented here describes spontaneous closure of hymen during pregnancy. We aim to report a rare case of spontaneous closure of hymen in a 23-year old primigravidae in labour with no prior history of menstrual problems or problems during intercourse. We also aim to highlight the importance of vaginal examination in detecting similar problems during antenatal period.

\section{CASE REPORT}

A 23-year old primigravidae at 38 weeks +5 days gestation age was seen at our hospital with labour pains. The patient was referred from a peripheral hospital with complaints of Vaginal atresia. Detailed menstrual and sexual history was obtained. She attained menarche at 16 years and had regular menstrual cycles since then. She had regular coital until the pregnancy was confirmed.

On initial per abdominal examination patient had 3 uterine contractions lasting for duration of 30 seconds, FHR 140bpm, cephalic presentation, vaginal examination was not possible due to a fully intact and bulging hymen. Ultrasonography revealed a single live intrauterine fetus of 38 weeks that was corresponding to gestational age with adequate liquor. Her CTG was reactive. She was immediately taken for emergency LSCS and a live term 
small for gestational age male baby was extracted on $26 / 9 / 13$ at $11: 40 \mathrm{am}$, weighing $2.28 \mathrm{~kg}$ with an apgar score of $7 / 9$ at $1 \mathrm{~min}$ and $5 \mathrm{mins}$. Post caesarean, stellate incision was given on the hymen and separated by artery forceps to drain the collected blood. Per speculum showed a single cervix with external os closed. Biopsy was taken from the membrane and sent for Histopathology, which showed normal hymenal tissue.

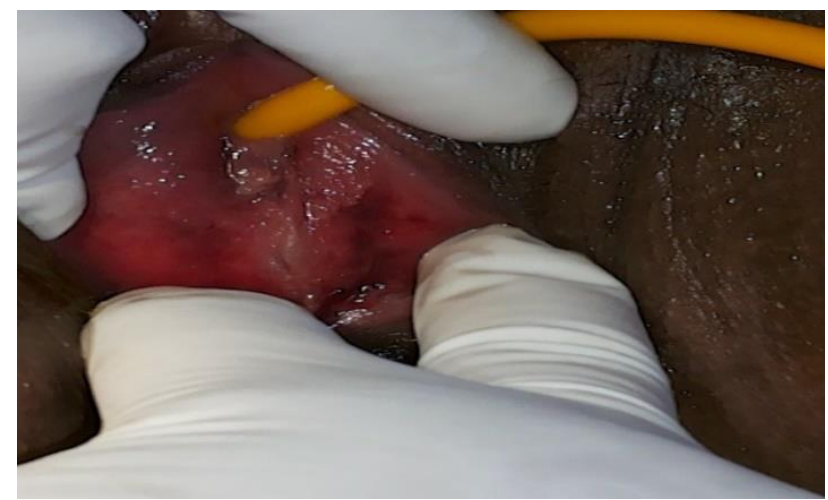

Figure 1: Intact hymen before surgical intervention.

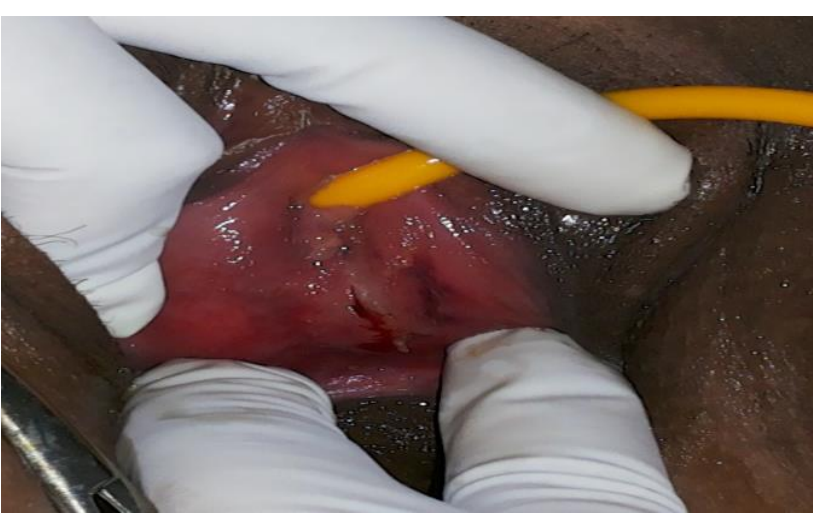

Figure 2: Linear incision put over hymen.

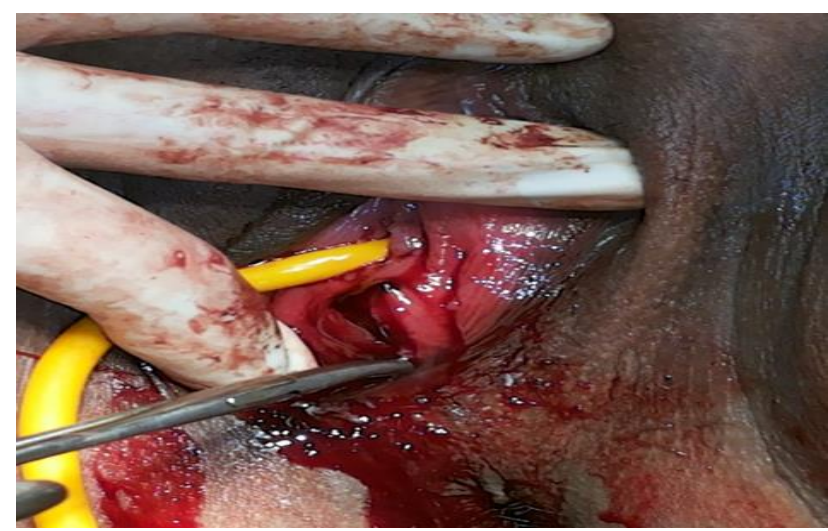

Figure 3: Vaginal drainage after C-section

Post correction follow up was done and she had a patent hymenal orifice at $6^{\text {th }}$ postpartum week. The couple began coital activity and has not reported any coital or menstrual problem until now.

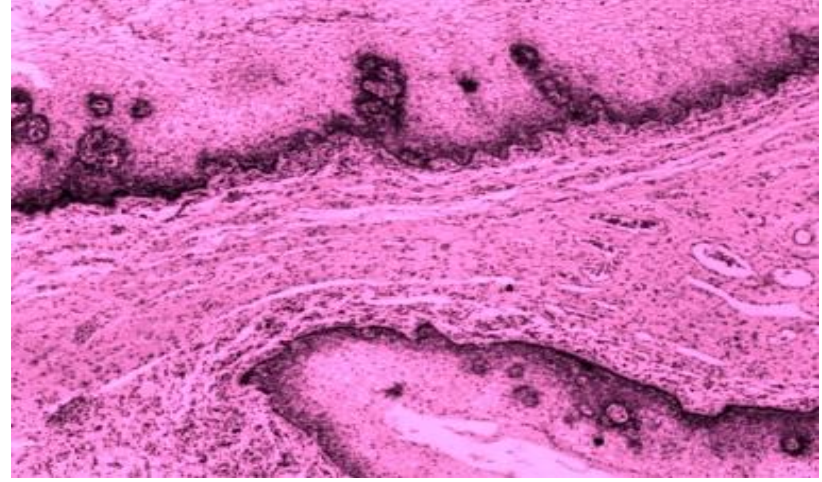

Figure 4: Histopathology of hymen.

Grey white soft tissue bit measuring $1 * 1 \mathrm{~cm}$ taken.

Microscopy: Section studied shows collagenous tissue lined by non-stratified squamous epithelium. No granulomas or dysplasia noted

\section{DISCUSSION}

Hymen is an embryologic remnant that usually perforates during the later stages of embryonic development and remains as a thin fold of mucous membrane. ${ }^{1,2}$ Hymen anomalies occur if the genital tubercle fails to breakdown or rupture. ${ }^{3}$ Pregnancy in Imperforate hymen can be attributed to either microperforate hymen or to secondary closure of hymen during pregnancy. ${ }^{4}$ Two conditions have been reported to cause the secondary closure of the hymen:

- Following previous scarring (sexual abuse) and

- Another two cases in pregnancy: one was due to previous surgical incision of the hymen at an early age suggesting the closure was related to extensive scar formation and the other closed spontaneously during pregnancy in the absence of previous surgical procedures. $^{5-8}$

The cessation of coital activity during pregnancy may cause a healing process which explains the spontaneous closure. Onen et al reported a case similar to ours in which a hymenal biopsy was taken during delivery to evaluate the ultra-structure of hymen by Electron microscopy (Carl Zeiss Em900; Zeiss, Jene, Germany). The connective tissue cells demonstrated markedly increased rough endoplasmic reticulum and free ribosomes. Between these cells, vascularization of connective tissue collagen fibres were obvious. This indicated reorganized hymenal tissue. ${ }^{7}$

\section{CONCLUSION}

This case of spontaneous closure of hymen in the absence of previous surgical procedures might be attributed to glycogenated epithelium which is a response to oestrogen exposure at pregnancy. ${ }^{9}$ It may also be due to sexually transmitted diseases like gonorrhea or extensive scaring. 
If STDs are considered as a cause of spontaneous closure, partner also needs to be evaluated and treated. In this patient if the closure was detected during her antenatal checkup and treated, we could have given her a vaginal delivery.

Funding: No funding sources

Conflict of interest: None declared

Ethical approval: Not required

\section{REFERENCES}

1. Mehran M, Saleh AM. The microscopic anatomy of the hymen. Anat Rec 1964;149:313-8.

2. Hegazy AA, Al-Rukban MO. Hymen: facts and conceptions. Health. 2012;3(4):109-15.

3. Bhatnagar KP, Nettleton, GS and Nakajima ST. Female genital anomalies affecting reproduction. Fertil Steril. 2002;78:899-915.

4. Davut G, Kadir B, Kurvoglu S. Micro perforate hymen and infertility. O J Obstet Gynecol. 2012;2:287-8.
5. Berkowitz CD, Evlik SL, Logan M. A simulated acquired imperforate hymen following genital trauma of sexual abuse. Clin Pediatr (Phila) 1987;26:307-9.

6. Chao-Hsi L, Ching-Chung L. Hymen reformation after hymenotomy associated with pregnancy. Aust NZ J Obstet Gynaecol. 2002;42:559-60

7. Edmonds DK. Congenital malformations of the genital tract and their management. Best Pract Res Clin Obstet Gynecol. 17 $7^{\text {th }}$ ed; 2003:29-40.

8. Onan MA, Turp AB, Taskiran C. Spontaneous closure of the hymen during pregnancy. AJOG. 2005;193:889-91.

9. Bereck JS, Rinchart RD, Berek and Novaks gynaecology- $14^{\text {th }}$ ed. California, Lippincott William and Wilkins: 2011.

Cite this article as: Gomathy E, Poonguzhali L, Shilpa G. Spontaneous closure of the hymen during term pregnancy. Int J Reprod Contracept Obstet Gynecol 2017;6:3670-2. 